\section{SAT0063 BLEEDING TIME AND PLATELET FUNCTION IN NORMAL VOLUNTEERS RECEIVING MELOXICAM}

${ }^{1} \mathrm{HM}$ Rinder, ${ }^{2} \mathrm{RP}$ Gagnier, ${ }^{2} \mathrm{M}$ Souhrada, ${ }^{2} \mathrm{CC}$ Wood. ${ }^{1}$ Department of Laboratory Medicine, Yale School of Medicine, New Haven, USA; ${ }^{2}$ Clinical Research, Boehringer Ingelheim Pharmaceuticals Inc., Ridgefield, USA

\subsection{6/annrheumdis-2001.438}

Background Traditional NSAIDs relieve the inflammation and pain of arthritis through inhibition of cycloxygenase (COX)-2, but adverse gastrointestinal and platelet side effects are common with inhibition of COX-1. Because meloxciam inhibits COX-2 to a greater degree than COX-1, it may therefore have inflammatory efficacy without adverse effects on platelet function.

Objectives This study assessed the effects of once daily meloxicam $(7.5,15$, and $30 \mathrm{mg})$ on bleeding time and platelet function in healthy subjects as compared to placebo or extended-release indomethacin capsules $(75 \mathrm{mg}$ ) as an active control.

Methods In this double-blind study, healthy male and female subjects were randomised to received 8 days of a single dose of meloxicam $7.5 \mathrm{mg}(\mathrm{N}=16), 15 \mathrm{mg}(\mathrm{N}=16)$, or $30 \mathrm{mg}(\mathrm{N}=$ 16), placebo $(\mathrm{N}=16)$, or indomethacin $\mathrm{ER} 75 \mathrm{mg}(\mathrm{N}=15)$. Subjects were serially evaluated with bleeding times (simplate method), platelet aggregation to Arachidonic acid (AA) and ADP, and serum thromboxane $\mathrm{B}_{2}\left(\mathrm{TXB}_{2}\right)$ levels. Changesfrom the predrug baseline were evaluated on Day 8 prior to drugdosing and at 3 and $6 \mathrm{~h}$ after dosing.

Results None of the meloxicam doses prolonged the bleeding time, either chronically (Day 8 predose) or acutely (Day 8, 3 and $6 \mathrm{hrs}$ post-dose) in comparison with placebo. By contrast, indomethacin significantly prolonged the bleeding time $6 \mathrm{hrs}$ after dosing on Day 8. Similar to the bleeding time results, there was no inhibitory effect of meloxicam at any dose on either ADP- or AA-induced platelet aggregation when compared with placebo; whereas indomethacin significantly inhibited platelet aggregation to ADP (Day 8, 3 and $6 \mathrm{hrs}$ post-dose) and to AA (Day 8, pre-dose and 3 and 6 hrs post-dose $(\mathrm{p}<0.05)$.

\begin{tabular}{lll}
\multicolumn{2}{l}{ Abstract SAT0063 Table 1} & \\
\hline & $\begin{array}{l}\text { Bleeding Time } \\
\text { (mean } \pm \text { SE) }\end{array}$ & $\begin{array}{l}\text { Platelet Aggregation } \\
\text { (mean } \pm \text { SE) }\end{array}$ \\
\hline Placebo & $0.2 \pm 0.4 \mathrm{~min}$ & $-1.3 \pm 3.1 \%$ \\
Meloxicam 7.5 & $0.4 \pm 0.3 \mathrm{~min}$ & $0.9 \pm 5.6 \%$ \\
Meloxicam 15 & $-0.2 \pm 0.5 \mathrm{~min}$ & $-2.3 \pm 3.8 \%$ \\
Meloxicam 30 & $0.7 \pm 0.5 \mathrm{~min}$ & $2.4 \pm 3.6 \%$ \\
Indomethacin ER 75 & $1.6 \pm 0.5 \mathrm{~min}$ & $-69.3 \pm 3.6 \%{ }^{*}$ \\
\hline${ }^{*} \mathrm{P}<0.05$ vs placebo. & &
\end{tabular}

Conclusion Meloxicam at higher than recommended doses had no acute or chronic effect on bleeding times and did not inhibit either AA or ADP induced platelet aggregation in healthy volunteers.

By contrast indomethacin ER $75 \mathrm{mg}$ significantly reduced platelet aggregation and increased bleeding times.
SAT0064 TREATMENT WITH ETORICOXIB (MK-0663), A COX-2 SELECTIVE INHIBITOR, RESULTED IN CLINICAL IMPROVEMENT IN KNEE OSTEOARTHRITIS (OA) OVER 52 WEEKS

${ }^{1} \mathrm{SP}$ Curtis, ${ }^{2} \mathrm{C}$ Fisher, ${ }^{3} \mathrm{~S}$ Kafka, ${ }^{4} \mathrm{~B}$ Bockow, ${ }^{5} \mathrm{~A}$ Ko, ${ }^{1} \mathrm{~A}$ Compton, ${ }^{1} \mathrm{~B}$ Pramanik, ${ }^{1} \mathrm{BJ}$ Gertz. ${ }^{1}$ Clinical Research; ${ }^{2}$ Clinical Research, Health Research of Hampton Roads, Newport News; ${ }^{3}$ Clinical Research, Altoona Center, Duncansville; ${ }^{4}$ Clinical Research, Arthritis Northwest, Seattle, USA; ${ }^{5}$ Biostat, Merck \& Co., Rahway

\subsection{6/annrheumdis-2001.439}

Background Prostanoid synthesis is catalysed by two distinct cyclooxygenase (COX) isoforms; COX-1 (constitutive) and COX-2 (inducible). NSAIDs such as aspirin and ibuprofen inhibit both COX isoforms. Etoricoxib has been characterised as a COX-2 selective inhibitor with doses up to $150 \mathrm{mg}$ QD ( 100fold selective in human whole blood assay).

Objectives Evaluate long-term efficacy following dose range finding of etoricoxib in knee OA.

Methods Double-blind, randomised, placebo-controlled, multicenter study conducted in 617 knee OA patients. Patients with increased pain after NSAID withdrawal were allocated to $\mathrm{qd}$ oral etoricoxib $5 \mathrm{mg}(\mathrm{N}=117), 10 \mathrm{mg}(\mathrm{N}=114), 30 \mathrm{mg}(\mathrm{N}=$ $102), 60 \mathrm{mg}(\mathrm{N}=112), 90 \mathrm{mg}(\mathrm{N}=112)$ or placebo $(\mathrm{N}=$ $60)$. Following Part I (6 weeks), patients continued in doubleblind continuation studies (total treatment 52 weeks). Patients receiving placebo, etoricoxib 5 and $10 \mathrm{mg}$ in Part I were reallocated to etoricoxib 30-, 60-, $90 \mathrm{mg}$, or diclofenac $150 \mathrm{mg}$ in the continuation studies. Etoricoxib 30-, 60-, and $90 \mathrm{mg}$ remained constant over 52 weeks.

Results In Part I, etoricoxib 5-, 10-, 30-, 60-, and 90 mg demonstrated significantly greater efficacy than placebo for the primary endpoints ( $p<0.05$ ), with effect sizes exhibiting a strong, doserelated trend. For the subset of patients remaining in the etoricoxib 30-, 60-, $90 \mathrm{mg}$ groups over 52 weeks, the treatment effect was generally maintained. Similar to the results in Part I, the 60- and 90-mg treatments were shown to be more effective than the $30-\mathrm{mg}$ dose with respect to each of the 3 primary efficacy endpoints (WOMAC VA 3.0 pain subscale, patient and investigator global assessment of disease status).

Etoricoxib was generally well tolerated over 52-weeks. In Part I, the incidence of patient discontinuation due to adverse events (AEs) was not significantly different between MK-663 and placebo. There were no clinically significant dose-related trends across treatments with $>=1$ AEs, drug-related AEs, serious AEs, or drug-related serious AEs. The safety results through 52 weeks were consistent with those in Part I, with no evidence of new types of AEs arising.

Conclusion Etoricoxib was generally well tolerated in doses up to $90 \mathrm{mg}$ in patients with OA for up to 52 weeks, and resulted in sustained clinical efficacy.

\section{SAT0065 META-ANALYSIS OF NSAID-INDUCED GASTROINTESTINAL (GI) SIDE EFFECTS IN OA PATIENTS IN JAPAN}

${ }^{1} \mathrm{~T}$ Ochi, ${ }^{2} \mathrm{~K}$ Sugano, ${ }^{3} \mathrm{~S}$ Uemura, ${ }^{4} \mathrm{R}$ Makuch. ${ }^{1}$ Department Orthopedics, Osaka University, Osaka; ${ }^{2}$ Department Gastroenterology, Jichi Medical School, Tocihgi; ${ }^{3}$ Department Biostatistics, University of Tokyo, Tokyo, Japan; ${ }^{4}$ Division Biostatistics, Yale University, New Haven, CT, USA

10.1136/annrheumdis-2001.440 